\title{
Geoelectrical investigation of groundwater potential, at Nigerian Union of Teachers Housing estate, Paggo, Minna, Nigeria
}

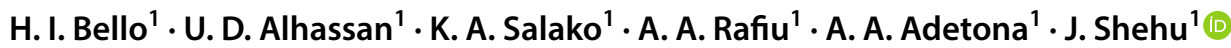

Received: 7 June 2018 / Accepted: 6 March 2019 / Published online: 22 March 2019

(c) The Author(s) 2019

\begin{abstract}
Vertical electrical sounding (VES) was carried out to evaluate the groundwater potentials of Nigerian Union of Teachers Housing estate, Paggo, Minna. The ABEM Terrameter model SAS 4000 was used to collect the subsurface data for the evaluation of groundwater potentials. Six profiles with ten VES stations on each profile were sounded with intervals of $100 \mathrm{~m}$ apart. It has a maximum current electrode separation $(\mathrm{AB} / 2)$ of $100 \mathrm{~m}$. Three and four geoelectric layers were obtained which include: topsoil, weathered layer, fractured layer and fresh basement layer. The stratigraphy of the subsurface shows: topsoil (67.5-835.1 $\Omega \mathrm{m})$, weathered layer (108.0-939.7 $\Omega \mathrm{m})$, fractured layer (118.9-242.0 $\Omega \mathrm{m})$ and the fresh basement layer (1041.0-9704.0 $\Omega \mathrm{m})$. Sixteen VES points were recommended as groundwater potentials of the area having weathered/ fractured layer resistivity varying between 65.84 and $454 \Omega \mathrm{m}$, depths range from 10.61 to $26.37 \mathrm{~m}$, and thickness varies between 9.255 and $24.69 \mathrm{~m}$. The observed frequencies in curve types include $58.33 \%$ of $\mathrm{H}, 26.67 \%$ of A, $10 \%$ of $\mathrm{HA}$ and $5 \%$ of AA. A correlation of the borehole log data with the VES was made and is in agreement. Viable boreholes for good portable water should be sited at VES stations $\mathrm{A}_{10}$ and $\mathrm{D}_{9}$ with a reasonable thickness of 21.2 and $10.68 \mathrm{~m}$, respectively.
\end{abstract}

Keywords Geoelectric $\cdot$ Evaluation · Vertical electrical sounding $\cdot$ Longitudinal unit conductance $\cdot$ Overburden protective capacity $\cdot$ Groundwater potential

\section{Introduction}

The growth of any community is hinged on the availability of basic amenities such as water, good road network and electricity. The search for sustainable, clean and portable water is a struggle that will never end as it aids in the growth of any community (Salako et al. 2009).

Niger State in north central Nigeria experiences an annual rainfall which ranges from $1200 \mathrm{~mm}$ to $1600 \mathrm{~mm}$ from the southern part of the state to the northern region. The duration of the rainy season ranges from 120 to 150 days or more from the north to the south (Baimba 1978). The amount of rainfall is usually limited to few months within the year, such that water from surface sources cannot meet the demand for development (Baimba 1978). This inadequacy and pollution of surface water brings about the overdependence on

J. Shehu

jameelshehu@futminna.edu.ng

1 Department of Physics, Federal University of Technology, Minna, Nigeria groundwater from hand dug well and borehole either for individual or public consumption.

Mapping of the subsurface structure and interpretation has provided information about the geologic formations and physical properties of the geologic materials (George et al. $2015 \mathrm{a}, \mathrm{b})$. In groundwater exploration, the knowledge of the aquifer characteristics is important as it helps in determination of natural flow of water, depth to bedrock, availability, quantity and quality of the groundwater. Since water occurs both as surface water and groundwater thus forming the hydrological cycle (a continuous re-circulatory movement of waters of the earth).

Groundwater is the water in porous rocks beneath the water table. In other words, it is the water that is contained in aquifers. An aquifer is any geologically deposited material that has the ability to store and transmit significant quantity of water. Groundwater contains dissolved ions and allows current to flow through it due to the conductive nature of the ions. Permeability, porosity, resistivity, thickness of the layers and aquifer yield are subsurface properties that play important role in groundwater movement, availability and potential. Aquifers are found deep beneath the earth's 
surface, and due to their depth of storage and natural filtration through the different subsurface layers (soil horizons), groundwater is relatively pure and grossly protected from surface pollutants. Groundwater is a source of uncontaminated water and is very important for our daily needs like drinking and even agricultural purposes. Groundwater is of major importance to civilization because it is the largest reserve of drinkable water in the regions where humans live. Groundwater may appear at the surface in the form of springs, or it may be tapped by wells/boreholes (Salako et al. 2009). Therefore, to have a sustainable groundwater development for our needs, the study of groundwater potentials becomes very important.

The subsurface is made up of different geologic materials occurring at varying depths. In a basement complex terrain, the lithological unit that can be observed comprises of the weathered layer, weathered/fracture basement and fresh basement (Omorinbola 1984). The porosity and permeability capacity of this subsurface lithology depends on the type of geologic material occupying them (Ojo and Olorunfemi, 1990). Weathered layer that consists of clay would have less porosity, while a highly weathered/fracture basement would be highly porous and permeable (Hazell 1992).

\section{Geology of the study area}

The study area is located at Paggo village in Minna, Niger State. It lies in north central Nigerian Basement Complex with latitude $9^{\circ} 27^{1} \mathrm{~N}$ and $9^{\circ} 28^{1} \mathrm{~N}$ and longitude $6^{\circ} 38^{1} \mathrm{E}$ and $6^{\circ} 39^{1} \mathrm{E}$. The mean annual temperature is $22-25^{\circ} \mathrm{C}$. The area is characterized by both dry and rainy seasons. It has an average rainfall of $1200-1300 \mathrm{~mm}$. The vegetation covering this area is Guinea savannah which is characterized by tall grasses, shrubs and also sparsely distributed trees. Dry season is usually accompanied by dust and fogs. The dry season usually last within the month of November to February followed by the rainy season from April to October. Most of the rocks are granite, gneiss and quartzite. Niger state has two main rock formations like most state that is on the same latitudes which are sedimentary and basement complex rocks (Amadi et al. 2012) (Fig. 1).

\section{Materials and method of the study}

The data were acquired with the ABEM SAS 4000 Terrameter, Global Positioning System (GPS) for taking accurate coordinate of the VES point and elevations, metal electrodes, measuring tape, labelled tag (used in locating station position), hammer (used in driving the electrodes into the ground). The Schlumberger array was adopted. The electrode spread of $\mathrm{AB} / 2$ was varied from 1 to a maximum of $100 \mathrm{~m}$. The electrical resistances obtained were multiplied by the corresponding geometric factor $(k)$ for each electrode separation to obtain the apparent resistivity. The apparent resistivity was computed using Eq. (1). Sounding data were presented as sounding curves, by plotting apparent resistivity against $A B / 2$. The IPI2win software was then used to obtain the $n$-layer model curve for the Schlumberger
Fig. 1 Geological map of Niger state showing basement complex and sedimentary basin (Amadi et al. 2012)

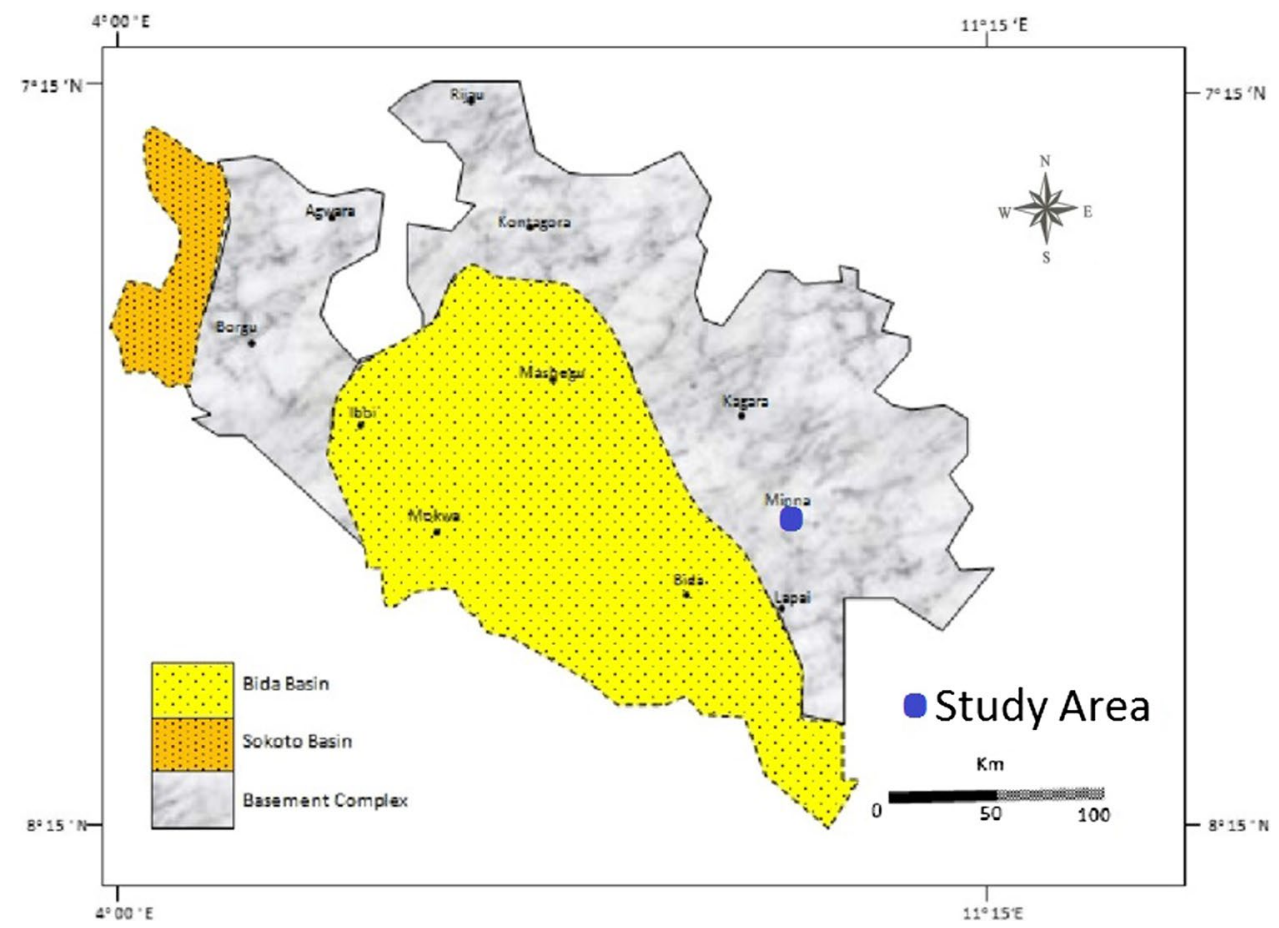


Table 1 Resistivity values of rock types (Ajayi and Hassan 1990)

\begin{tabular}{ll}
\hline Rock Type & Resistivity $(\Omega \mathrm{m})$ \\
\hline Fadama loam & $30-90$ \\
Sandy & $100-200$ \\
Sand and gravel & $100-180$ \\
Weathered and laterite & $150-900$ \\
Fresh laterite & $900-3500$ \\
Weathered basement & $20-200$ \\
Fractured basement & $500-1000$ \\
Fresh basement & $>1000$ \\
\hline
\end{tabular}

Table 2 Longitudinal conductance/protective capacity rating (Ogungbemi et al. 2013)

\begin{tabular}{ll}
\hline $\begin{array}{l}\text { Longitudinal } \\
\text { conductance } \\
\text { (mho) }\end{array}$ & $\begin{array}{l}\text { Protective } \\
\text { capacity } \\
\text { rating }\end{array}$ \\
\hline$>10$ & Excellent \\
$5-10$ & Very good \\
$0.7-4.9$ & Good \\
$0.2-0.69$ & Moderate \\
$0.1-0.19$ & Weak \\
$<0.1$ & Poor \\
\hline
\end{tabular}

sounding curves. This software automatically interprets the Schlumberger sounding curves. The plotted curves reveal the number of layers, thickness, depth and the average resistivity for each layer at different VES points automatically.

$\rho_{\mathrm{a}}=K R$

where $\rho_{\mathrm{a}}$ is an apparent resistivity and the earth resistance $(R)$ is given as

$R=\frac{\Delta V}{I}$

The geometric factor, $K$, is expressed as

$K=\pi\left(\frac{\left(\frac{\mathrm{AB}}{2}\right)^{2}-\left(\frac{\mathrm{MN}}{2}\right)^{2}}{\mathrm{MN}}\right)$

The aquifer protective capacity characterization is based on the values of the longitudinal unit conductance of the overburden rock units in the area. The longitudinal layer conductance $(S)$ of the overburden at each VES station was obtained from Eq. (4). Table 1 gives the resistivity range with corresponding subsurface earth material (Ajayi and Hassan 1990) and Table 2 represents the protective capacity rating (Ogungbemi et al. 2013)

$S=\sum_{i=1}^{n} \frac{h i}{\rho i}$ where $h$ is the saturated thickness of each layer and $p$ is the layer resistivity

The interpretation of the resistivity value for the n-layers was done for 60 VES points. The surfer 11 computer programme was then used to produce iso-resistivity contour maps from the obtained data. The VES plots along the various profiles generate the geoelectric sections from where the resistivity variation with depth and thickness was obtained (Fig. 2).

\section{Results and discussion}

The results were summarized in a tabular form, giving information about the average layer resistivity, depth of each layer, thickness and the curve types (Table 3), while geoelectric section where the parameters in Table 3 were obtained is presented in Fig. 2.

\section{Iso-resistivity contour map for the first layer}

The iso-resistivity contoured map for the first layer was generated at an interval of $50 \Omega \mathrm{m}$ (Fig. 3). The resistivity values range from 50 to $950 \Omega \mathrm{m}$. The resistivity value shows that central portion of the area is a fadama loam, while sandy clay and gravels are located around southwest, northwest and north central parts of the area (Table 1).

\section{Iso-resistivity contour map of the second layer}

The iso-resistivity map for the second layer was generated at an interval of $50 \Omega \mathrm{m}$ (Fig. 4). Its resistivity values range from 0 to $1150 \Omega \mathrm{m}$. From the map, it is observed that fresh laterite is scattered around the area and weathered laterite concentrates around northeast and central part of the area (Table 1). The weathered/fractured layer resistivity ranges from 65.84 to $454.9 \Omega \mathrm{m}$, the depths of these weathered/ fractured layers were found to be from 10.61 to $26.37 \mathrm{~m}$ and thickness 9.26 to $24.69 \mathrm{~m}$, respectively. In a basement complex terrain, areas with overburden thickness of $15 \mathrm{~m}$ and above with fractured layer resistivity of $<1000 \Omega \mathrm{m}$ are good for groundwater development (Alhassan et al. 2015).

\section{Iso-resistivity map of the third layer}

The iso-resistivity map for the third layer was generated at an interval of $2000 \Omega \mathrm{m}$ (Fig. 5). The resistivity value ranges from 2000 to $2800 \Omega \mathrm{m}$. The resistivity values on this map indicate the fresh basement.

Iso-resistivity map of the fractured basement produced shows the resistivity distribution across the study area which varies from 50 to $950 \Omega \mathrm{m}$ (Fig. 6). The Isopach map of the fractured basement is produced which gives thickness of 


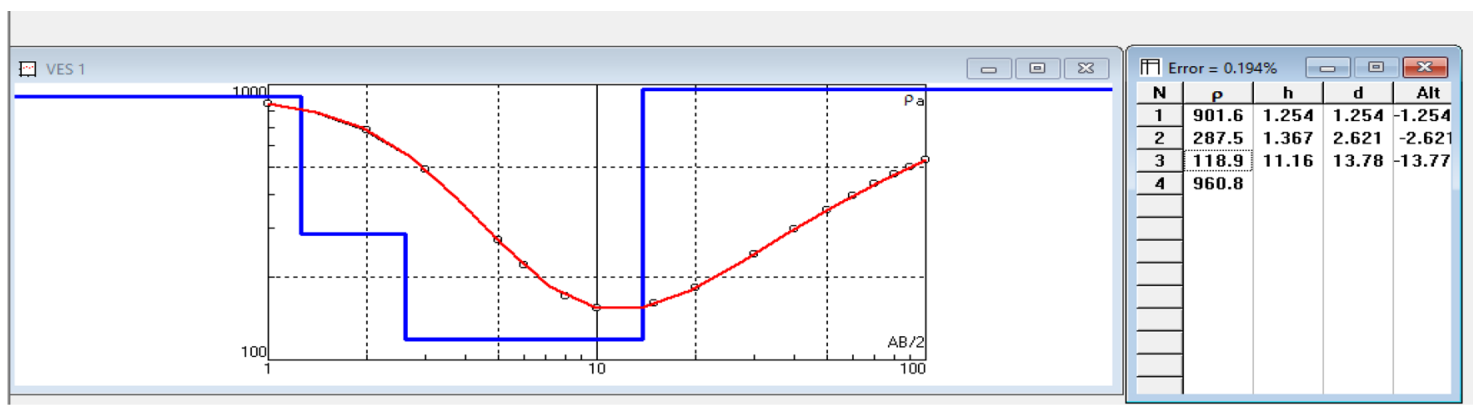

(a) Geoelectric Section (VES Curve $A_{1}$ )

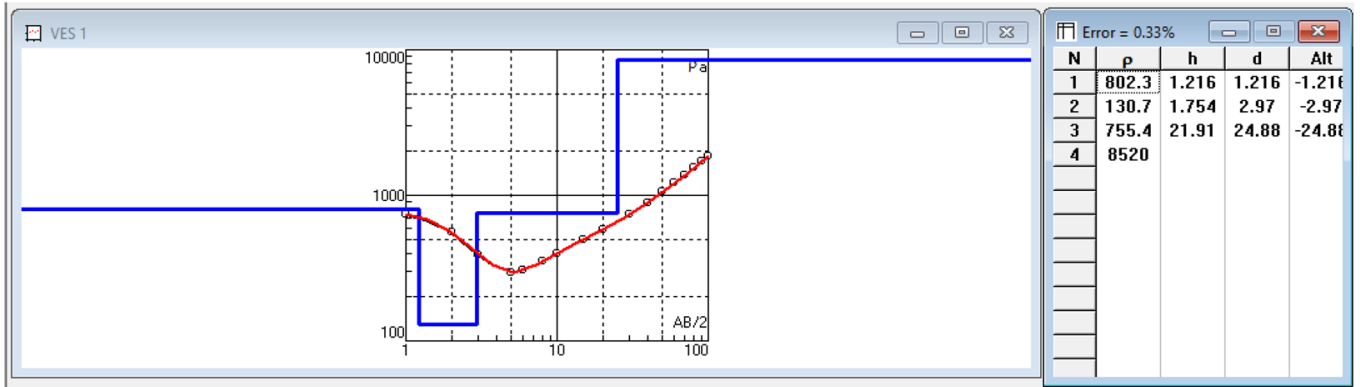

(b) Geoelectric Section (VES Curve $\mathrm{B}_{1}$ )

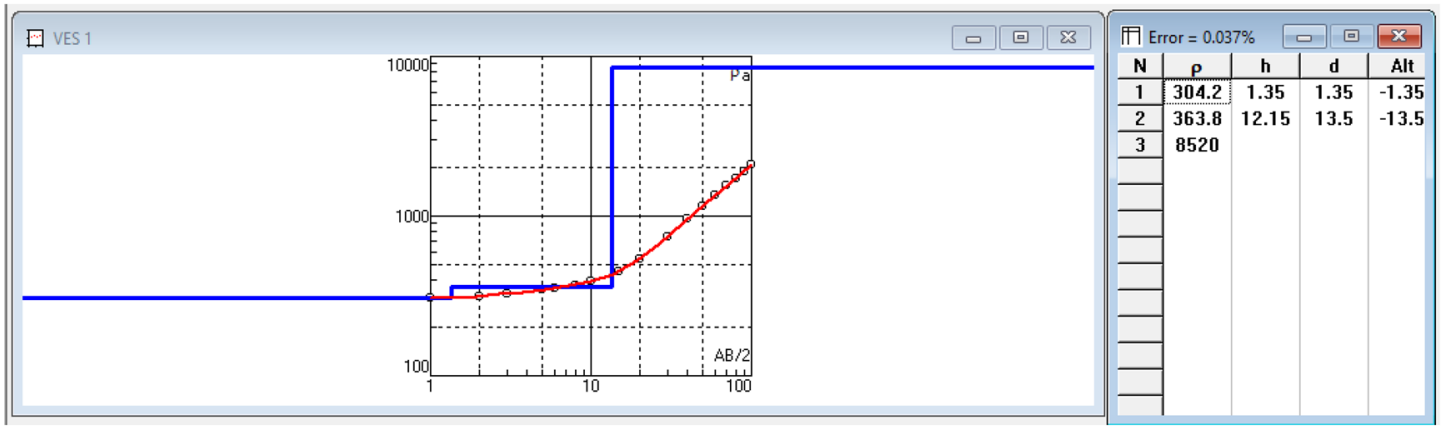

(c) Geoelectric Section (VES Curve $\mathrm{C}_{1}$ )

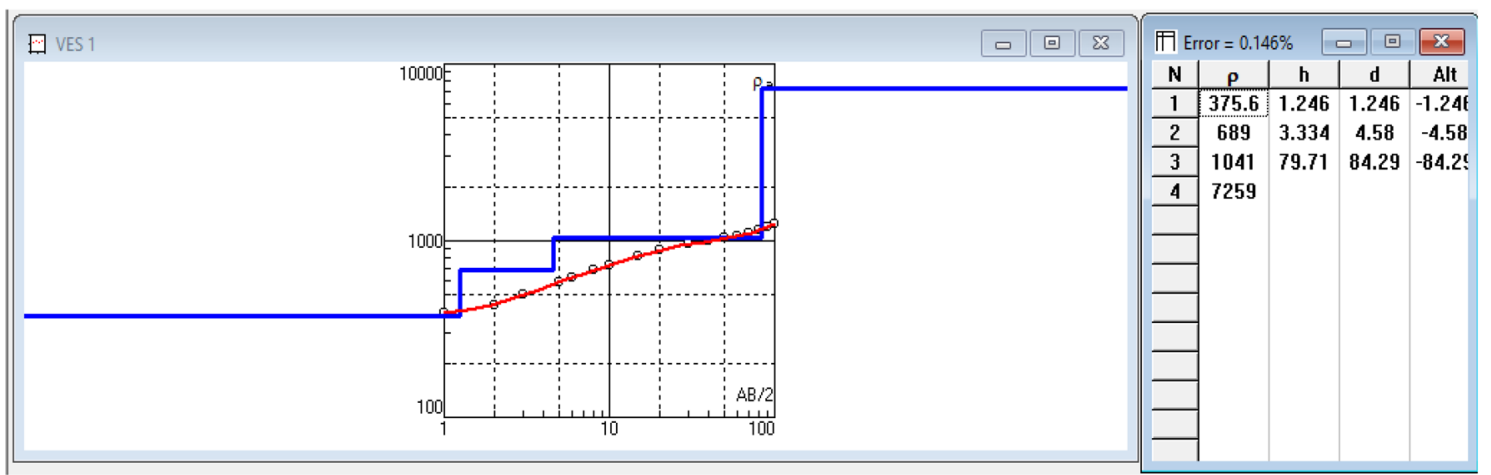

(d) Geoelectric Section (VES Curve $\mathrm{D}_{1}$ )

Fig. 2 Geoelectric Section a (VES curve $\left.A_{1}\right)$, b (VES curve $\left.B_{1}\right)$, c (VES curve $\left.C_{1}\right)$, d $\left(\right.$ VES curve $\left.D_{1}\right)$

the fractured basement across the area. The thickness varies between 1 and $23 \mathrm{~m}$ (Fig. 7). Isopach map of weathered layer is also produced, and it presents the thickness of the weathered basement within the study area (Fig. 8).
Isopach map of the overburden is produced. The map indicates that thick overburden is located around northwest, north central, north east, south east and south central portions of the area, while the shallow thickness is concentrated 
Table 3 Layer resistivity, depth and thickness

\begin{tabular}{|c|c|c|c|c|c|c|c|c|c|c|c|c|c|}
\hline \multirow[t]{2}{*}{ VES station } & \multirow[t]{2}{*}{ Latitude $\left({ }^{\circ}\right)$} & \multirow[t]{2}{*}{ Longitude $\left(^{\circ}\right)$} & \multirow[t]{2}{*}{ No. of layers } & \multicolumn{4}{|c|}{ Layer resistivity } & \multicolumn{3}{|c|}{ Layer depth } & \multicolumn{3}{|c|}{ Layer thickness } \\
\hline & & & & $\rho_{1}$ & $\rho_{2}$ & $\rho_{3}$ & $\rho_{4}$ & $d_{1}$ & $d_{2}$ & $d_{3}$ & $h_{1}$ & $h_{2}$ & $h_{3}$ \\
\hline $\mathrm{A}_{1}$ & 09.46521 & 06.63871 & 4 & 901.6 & 287.5 & 118.9 & 960.8 & 1.254 & 2.621 & 13.78 & 1.254 & 1.367 & 11.16 \\
\hline $\mathrm{A}_{2}$ & 09.46500 & 06.63832 & 4 & 399 & 586 & 652 & 7864 & 2.64 & 5.49 & 53.31 & 2.64 & 2.86 & 47.8 \\
\hline $\mathrm{A}_{3}$ & 09.46463 & 06.63797 & 3 & 684.8 & 112.8 & 8692 & & 1.222 & 3.403 & $\infty$ & 1.222 & 2.181 & $\infty$ \\
\hline $\mathrm{A}_{4}$ & 09.46435 & 06.63756 & 3 & 165 & 743.4 & 9231 & & 1.222 & 17.52 & $\infty$ & 1.222 & 16.3 & $\infty$ \\
\hline $\mathrm{A}_{5}$ & 09.46410 & 06.63720 & 4 & 816.9 & 173.7 & 367.5 & 8692 & 1.104 & 1.68 & 26.37 & 1.104 & 0.576 & 24.98 \\
\hline $\mathrm{A}_{6}$ & 09.46379 & 06.63683 & 3 & 213.3 & 123.6 & 5060 & & 2.133 & 3.68 & $\infty$ & 2.133 & 1.547 & $\infty$ \\
\hline $\mathrm{A}_{7}$ & 09.46360 & 06.63642 & 3 & 784.5 & 127.4 & 4960 & & 2.082 & 3.416 & $\infty$ & 2.082 & 1.334 & $\infty$ \\
\hline $\mathrm{A}_{8}$ & 09.46330 & 06.63602 & 3 & 715.7 & 293.5 & 3124 & & 2.183 & 21.4 & $\infty$ & 2.183 & 19.22 & $\infty$ \\
\hline $\mathrm{A}_{9}$ & 09.46294 & 06.63575 & 4 & 539.7 & 143.4 & 725.9 & 1249 & 1.585 & 2.056 & 18.98 & 1.585 & 0.471 & 16.92 \\
\hline $\mathrm{A}_{10}$ & 09.46264 & 06.63533 & 3 & 282.2 & 108 & 894 & & 1.25 & 22.4 & $\infty$ & 1.25 & 21.2 & $\infty$ \\
\hline $\mathrm{B}_{1}$ & 09.46567 & 06.63856 & 4 & 802.3 & 130.7 & 755.4 & 8520 & 1.216 & 2.97 & 24.88 & 1.216 & 1.754 & 21.91 \\
\hline $\mathrm{B}_{2}$ & 09.46538 & 06.63799 & 3 & 431 & 135 & 1094 & & 1.272 & 1.575 & $\infty$ & 1.272 & 0.303 & $\infty$ \\
\hline $\mathrm{B}_{3}$ & 09.46502 & 06.63739 & 3 & 353.9 & 137.6 & 9231 & & 1.222 & 3.825 & $\infty$ & 1.222 & 2.603 & $\infty$ \\
\hline $\mathrm{B}_{4}$ & 09.46469 & 06.63698 & 3 & 923 & 126.6 & 8692 & & 1.324 & 6.791 & $\infty$ & 1.324 & 5.467 & $\infty$ \\
\hline $\mathrm{B}_{5}$ & 09.46443 & 06.63658 & 3 & 741.4 & 173 & 8133 & & 1.197 & 5.791 & $\infty$ & 1.197 & 4.594 & $\infty$ \\
\hline $\mathrm{B}_{6}$ & 09.46413 & 06.63629 & 3 & 67.4 & 675 & 9132 & & 1.35 & 18.3 & $\infty$ & 1.35 & 17 & $\infty$ \\
\hline $\mathrm{B}_{7}$ & 09.46382 & 06.63595 & 3 & 251.1 & 939.7 & 9048 & & 1.222 & 24.33 & $\infty$ & 1.222 & 23.01 & $\infty$ \\
\hline $\mathrm{B}_{8}$ & 09.46353 & 06.63560 & 3 & 941.2 & 454.9 & 9231 & & 1.354 & 10.61 & $\infty$ & 1.354 & 9.255 & $\infty$ \\
\hline $\mathrm{B}_{9}$ & 09.46279 & 06.63505 & 3 & 913.1 & 108.3 & 4138 & & 1.199 & 3.569 & $\infty$ & 1.199 & 2.37 & $\infty$ \\
\hline $\mathrm{B}_{10}$ & 09.46278 & 06.63501 & 4 & 287 & 111 & 242 & 9231 & 1.2 & 2.04 & 17.1 & 1.2 & 0.837 & 15.1 \\
\hline $\mathrm{C}_{1}$ & 09.46609 & 06.63838 & 3 & 304.2 & 363.8 & 8520 & & 1.35 & 13.5 & $\infty$ & 1.35 & 12.15 & $\infty$ \\
\hline $\mathrm{C}_{2}$ & 09.46596 & 06.63795 & 3 & 685 & 149.2 & 7864 & & 2.228 & 6.438 & $\infty$ & 2.28 & 4.21 & $\infty$ \\
\hline $\mathrm{C}_{3}$ & 09.46572 & 06.63758 & 3 & 534.4 & 136.6 & 8200 & & 1.297 & 14.34 & $\infty$ & 1.297 & 13.04 & $\infty$ \\
\hline $\mathrm{C}_{4}$ & 09.46557 & 06.63718 & 3 & 106 & 148.4 & 942 & & 1.69 & 5.26 & $\infty$ & 1.69 & 3.56 & $\infty$ \\
\hline $\mathrm{C}_{5}$ & 09.46535 & 06.63672 & 3 & 181 & 289 & 923 & & 1.4 & 4.69 & $\infty$ & 1.4 & 3.29 & $\infty$ \\
\hline $\mathrm{C}_{6}$ & 09.46510 & 06.63634 & 3 & 786.4 & 177.2 & 1970 & & 1.324 & 5.02 & $\infty$ & 1.324 & 3.696 & $\infty$ \\
\hline $\mathrm{C}_{7}$ & 09.46483 & 06.63597 & 3 & 429.7 & 503.8 & 6437 & & 1.38 & 12.4 & $\infty$ & 1.38 & 11 & $\infty$ \\
\hline $\mathrm{C}_{8}$ & 09.46458 & 06.63562 & 3 & 835.1 & 186.4 & 8820 & & 1.297 & 4.412 & $\infty$ & 1.297 & 3.115 & $\infty$ \\
\hline $\mathrm{C}_{9}$ & 09.46424 & 06.63528 & 3 & 308.5 & 179.8 & 8859 & & 1.354 & 4.778 & $\infty$ & 1.354 & 3.424 & $\infty$ \\
\hline $\mathrm{C}_{10}$ & 09.46383 & 06.63491 & 3 & 332 & 113 & 905 & & 1.11 & 2.5 & $\infty$ & 1.11 & 1.39 & $\infty$ \\
\hline $\mathrm{D}_{1}$ & 09.46655 & 06.63817 & 4 & 375.6 & 689 & 1041 & 7259 & 1.246 & 4.58 & 84.29 & 1.246 & 3.334 & 79.71 \\
\hline $\mathrm{D}_{2}$ & 09.46630 & 06.63778 & 3 & 442.4 & 124.6 & 8351 & & 1.311 & 3.52 & $\infty$ & 1.311 & 2.209 & $\infty$ \\
\hline $\mathrm{D}_{3}$ & 09.46610 & 06.63736 & 4 & 307.1 & 548.4 & 662.6 & 8023 & 1.585 & 8.389 & 14.78 & 1.585 & 6.804 & 6.389 \\
\hline $\mathrm{D}_{4}$ & 09.46587 & 06.63693 & 3 & 146.6 & 594.2 & 4062 & & 4.864 & 26.14 & $\infty$ & 4.864 & 21.28 & $\infty$ \\
\hline $\mathrm{D}_{5}$ & 09.46569 & 06.63650 & 3 & 117 & 206.6 & 606 & & 1.251 & 3.611 & $\infty$ & 1.251 & 2.36 & $\infty$ \\
\hline $\mathrm{D}_{6}$ & 09.46538 & 06.63613 & 3 & 111.9 & 833.8 & 5624 & & 6.504 & 16.26 & $\infty$ & 6.504 & 9.757 & $\infty$ \\
\hline $\mathrm{D}_{7}$ & 09.46520 & 06.63573 & 3 & 887 & 210 & 905 & & 1.396 & 5.975 & $\infty$ & 1.396 & 4.579 & $\infty$ \\
\hline $\mathrm{D}_{8}$ & 09.46494 & 06.63538 & 3 & 385.9 & 559.5 & 7864 & & 1.505 & 35.27 & $\infty$ & 1.405 & 33.87 & $\infty$ \\
\hline $\mathrm{D}_{9}$ & 09.46465 & 06.63501 & 3 & 516.5 & 65.84 & 852 & & 1.787 & 12.47 & $\infty$ & 1.787 & 10.68 & $\infty$ \\
\hline $\mathrm{D}_{10}$ & 09.46429 & 06.63460 & 4 & 580.2 & 137.8 & 332 & 8186 & 1.26 & 2.743 & 17.11 & 1.26 & 1.483 & 14.37 \\
\hline $\mathrm{E}_{1}$ & 09.46704 & 06.63790 & 3 & 555.5 & 420 & 8520 & & 3.564 & 15.22 & $\infty$ & 3.654 & 11.66 & $\infty$ \\
\hline $\mathrm{E}_{2}$ & 09.46672 & 06.63721 & 3 & 617.2 & 886.8 & 6373 & & 2.96 & 23.8 & $\infty$ & 2.96 & 20.9 & $\infty$ \\
\hline $\mathrm{E}_{3}$ & 09.46640 & 06.63688 & 3 & 517.5 & 161.7 & 5307 & & 1.236 & 3.461 & $\infty$ & 1.236 & 2.225 & $\infty$ \\
\hline $\mathrm{E}_{4}$ & 09.46617 & 06.63649 & 3 & 171 & 112.8 & 8859 & & 1.354 & 4.196 & $\infty$ & 1.354 & 2.842 & $\infty$ \\
\hline$E_{5}$ & 09.46588 & 06.63613 & 3 & 145.1 & 1199 & 8595 & & 2.373 & 10.62 & $\infty$ & 2.373 & 8.251 & $\infty$ \\
\hline $\mathrm{E}_{6}$ & 09.46560 & 06.63574 & 3 & 168.2 & 326.4 & 9231 & & 1.405 & 14.63 & $\infty$ & 1.405 & 13.22 & $\infty$ \\
\hline $\mathrm{E}_{7}$ & 09.46533 & 06.63533 & 3 & 472 & 644 & 3587 & & 1.297 & 12.98 & $\infty$ & 1.297 & 11.68 & $\infty$ \\
\hline $\mathrm{E}_{8}$ & 09.46504 & 06.63494 & 3 & 697.4 & 116.4 & 9132 & & 1.354 & 6.843 & $\infty$ & 1.354 & 5.489 & $\infty$ \\
\hline
\end{tabular}


Table 3 (continued)

\begin{tabular}{|c|c|c|c|c|c|c|c|c|c|c|c|c|c|}
\hline \multirow[t]{2}{*}{ VES station } & \multirow[t]{2}{*}{ Latitude $\left({ }^{\circ}\right)$} & \multirow[t]{2}{*}{ Longitude $\left({ }^{\circ}\right)$} & \multirow[t]{2}{*}{ No. of layers } & \multicolumn{4}{|c|}{ Layer resistivity } & \multicolumn{3}{|c|}{ Layer depth } & \multicolumn{3}{|c|}{ Layer thickness } \\
\hline & & & & $\rho_{1}$ & $\rho_{2}$ & $\rho_{3}$ & $\rho_{4}$ & $d_{1}$ & $d_{2}$ & $d_{3}$ & $h_{1}$ & $h_{2}$ & $h_{3}$ \\
\hline $\mathrm{E}_{9}$ & 09.46473 & 06.63451 & 3 & 786.7 & 127.2 & 970.4 & & 1.274 & 13.68 & $\infty$ & 1.274 & 12.41 & $\infty$ \\
\hline $\mathrm{E}_{10}$ & 09.46443 & 06.63412 & 3 & 423 & 105.1 & 923 & & 1.199 & 2.976 & $\infty$ & 1.199 & 1.777 & $\infty$ \\
\hline $\mathrm{F}_{1}$ & 09.46746 & 06.63768 & 3 & 299 & 111 & 961 & & 3.57 & 5.9 & $\infty$ & 3.57 & 2.33 & $\infty$ \\
\hline $\mathrm{F}_{2}$ & 09.46734 & 06.63724 & 3 & 622.6 & 137.8 & 1901 & & 1.18 & 2.544 & $\infty$ & 1.18 & 1.364 & $\infty$ \\
\hline $\mathrm{F}_{3}$ & 09.46703 & 06.63681 & 3 & 653.7 & 146.3 & 2039 & & 1.174 & 2.304 & $\infty$ & 1.174 & 1.133 & $\infty$ \\
\hline $\mathrm{F}_{4}$ & 09.46677 & 06.63638 & 3 & 755.6 & 231.9 & 8692 & & 1.211 & 16.57 & $\infty$ & 1.211 & 15.29 & $\infty$ \\
\hline $\mathrm{F}_{5}$ & 09.46650 & 06.63600 & 3 & 650.9 & 281.7 & 4082 & & 1.557 & 17.17 & $\infty$ & 1.557 & 15.61 & $\infty$ \\
\hline $\mathrm{F}_{6}$ & 09.46621 & 06.63557 & 3 & 131.3 & 390.9 & 8595 & & 2.198 & 24.08 & $\infty$ & 2.198 & 21.88 & $\infty$ \\
\hline $\mathrm{F}_{7}$ & 09.46585 & 06.63514 & 3 & 562.6 & 354 & 1267 & & 1.553 & 8.521 & $\infty$ & 1.553 & 6.968 & $\infty$ \\
\hline $\mathrm{F}_{8}$ & 09.46552 & 06.63486 & 3 & 852 & 155.3 & 8186 & & 2.582 & 6.624 & $\infty$ & 2.582 & 4.042 & $\infty$ \\
\hline $\mathrm{F}_{9}$ & 09.46529 & 06.63436 & 3 & 546.4 & 157.5 & 7387 & & 1.313 & 2.86 & $\infty$ & 1.313 & 1.547 & $\infty$ \\
\hline $\mathrm{F}_{10}$ & 09.46497 & 06.63390 & 3 & 397.9 & 180 & 970.4 & & 1.129 & 16.64 & $\infty$ & 1.129 & 15.51 & $\infty$ \\
\hline
\end{tabular}

Fig. 3 Iso-resistivity contour map for the first layer

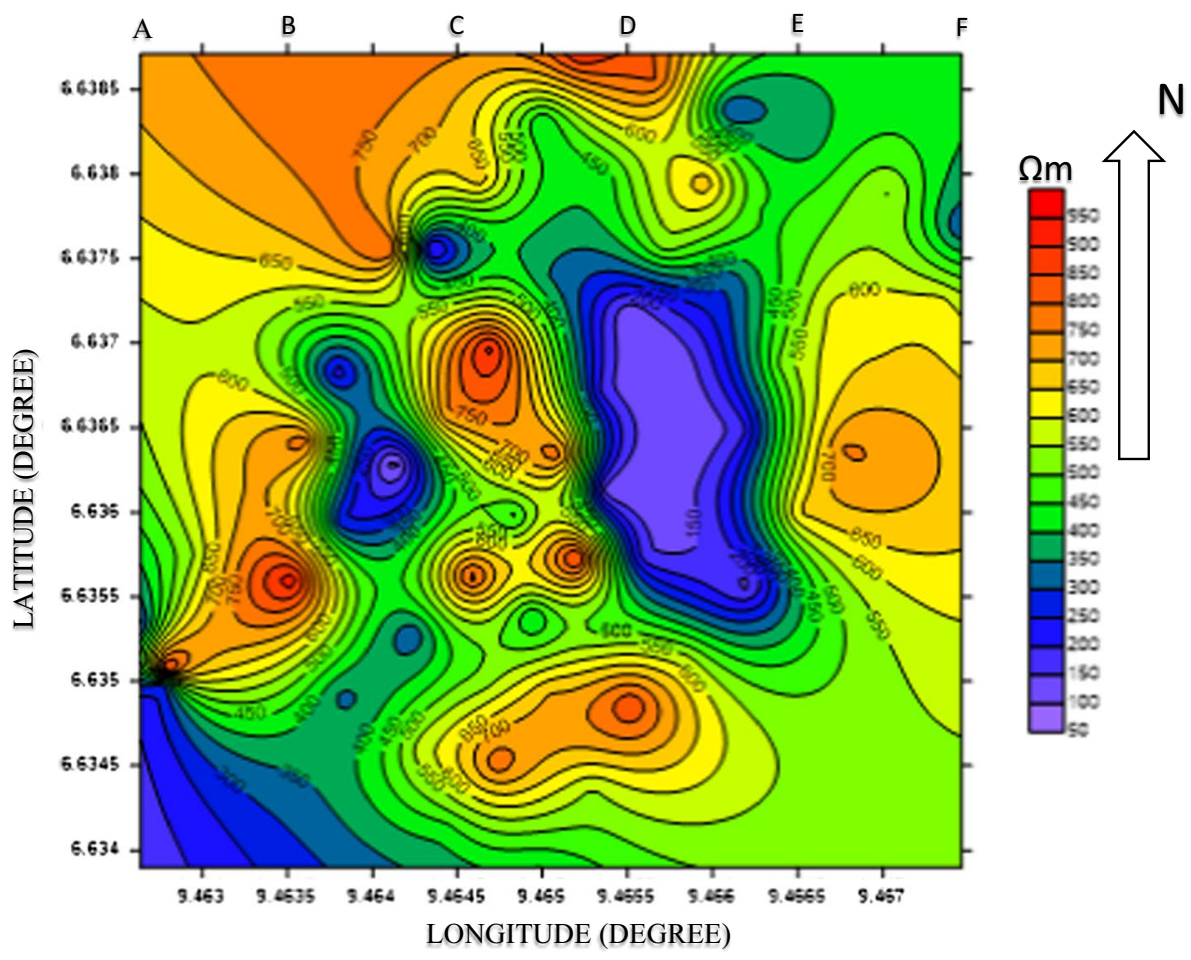

around extreme north, south west and central parts of the area (Fig. 9).

\section{Aquifer protective capacities evaluation}

The study revealed that the area is characterized with poor, weak and moderate protective capacities having a longitudinal conductance ranging from 0.01 to 0.30 . The longitudinal conductance values obtained were used to produce the longitudinal contour map which shows the distribution across the area (Fig. 10). The highest longitudinal conductance was seen at VES $B_{6}(0.30)$, and the lowest was seen at VES $B_{2}(0.004)$.

Table 4 shows 16 VES stations recommended as aquifer potentials of the area. The highest groundwater yield is often obtained from a fractured aquiferous zone or a subsurface sequence that has a combination of a significantly thick and sandy weathered layer and fractured aquifer (Olorunfemi et al. 1999). A correlation of the nearby borehole log with the VES formation (Fig. 11) is in agreement. 
Fig. 4 Iso-resistivity contour map of the second layer
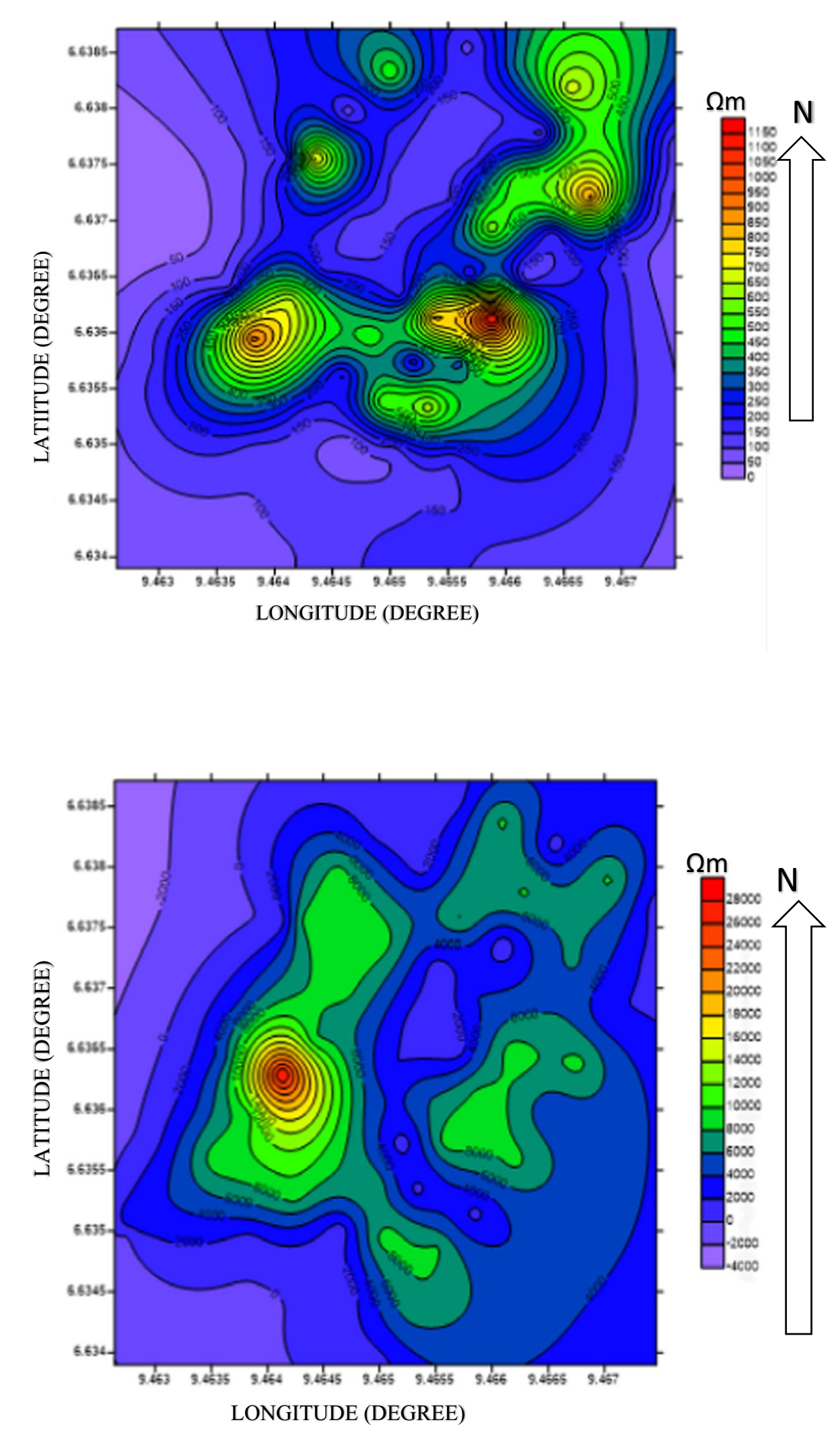

Fig. 5 Iso-resistivity contour map of the third layer 


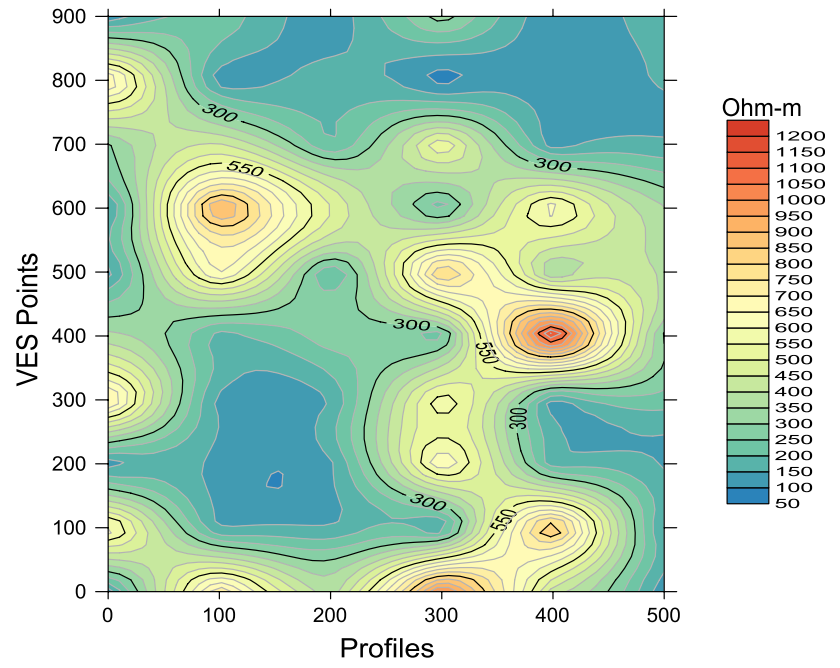

Fig. 6 Iso-resistivity map of the fractured basement

\section{The curve types}

The curve distribution (Fig. 12) indicates four types. The $\mathrm{H}$-type is the dominant curve with $35 \%$ of the area The weathered/fractured layer in the H-curve type is usually characterized with low resistivity value made up of clayey or sandy clay, and it is usually water saturated and highly porous (Olorunfemi et al. 1999). The A-curve type consists
$16 \%$ of the area, the HA curve type occupies $6 \%$, while the AA occupies $3 \%$ of the study area.

\section{Conclusion}

In the basement complex area, groundwater usually is found in a discontinuous aquifer. When defining the potentials of an aquifer formation, it comes with a tedious exercise due to the complexity properties of the basement rock (Alhassan et al. 2017). Therefore, the groundwater potentials of the study area were classified by employing the electrical resistivity of the fractured layer, the depth of the layer and the thickness of the layer. From the result, it is revealed that the subsurface consists of 3-4 lithologic units which are top layer, weathered layer, fractured layer and fresh basement. The curve types were identified as $\mathrm{H}, \mathrm{HA}, \mathrm{A}$ and AA. The geoelectric and geologic sections for the profile were produced. The aquifer potentials of the area show poor, weak and moderate protective capacities having longitudinal conductance ranging from 0.01 to 0.30 mho.

Sixteen VES stations were delineated as groundwater potentials of the study area, having fractured layer resistivity ranging from 65.84 to $454 \Omega \mathrm{m}$. The depths of these layers are found ranging from 10.61 to $26.37 \mathrm{~m}$ and thickness ranging from 9.255 to $24.69 \mathrm{~m}$. VES stations $A_{10}$ and $D_{9}$ are observed to have fine aquifer with depth
Fig. 7 Isopach map of the fractured basement

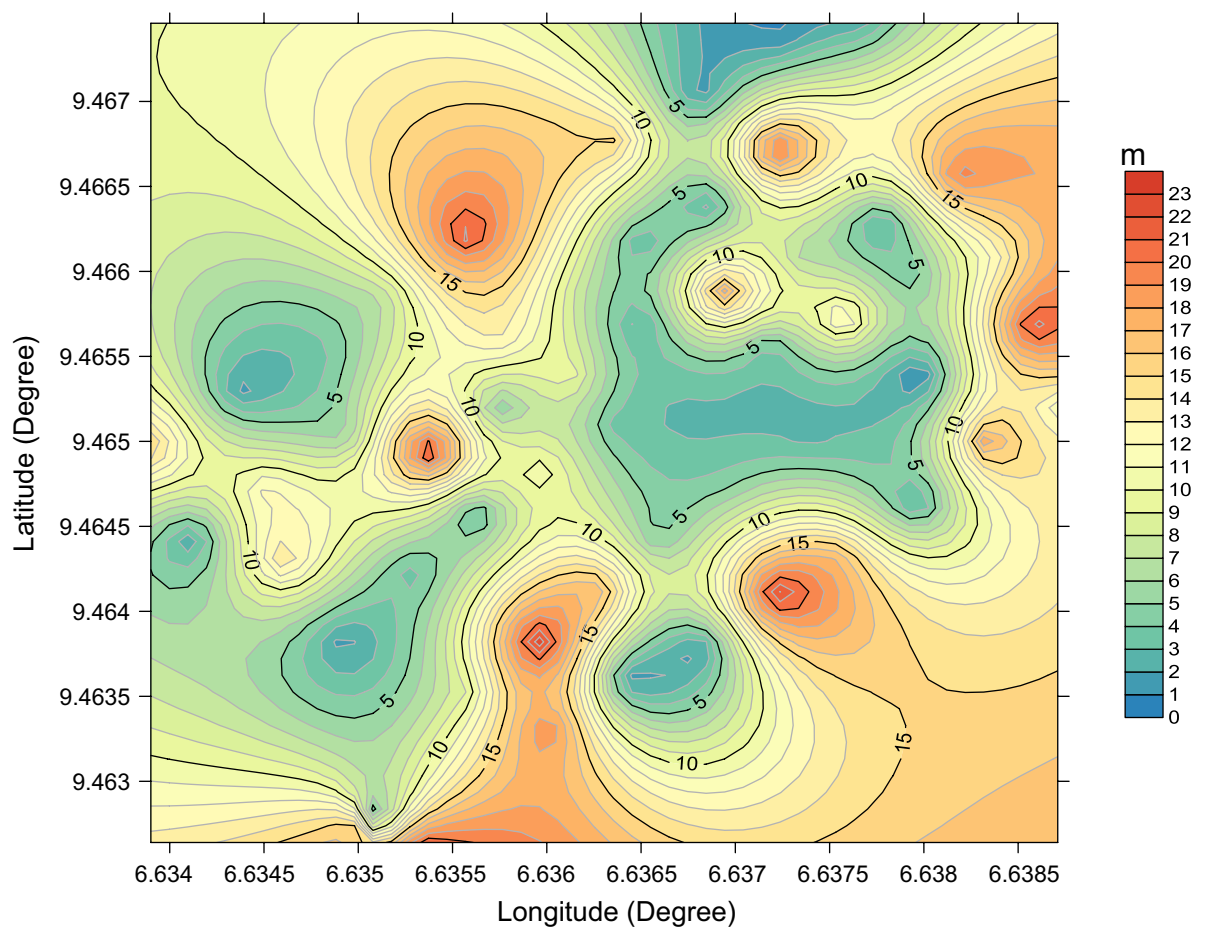


Fig. 8 Isopach map of the weathered layer
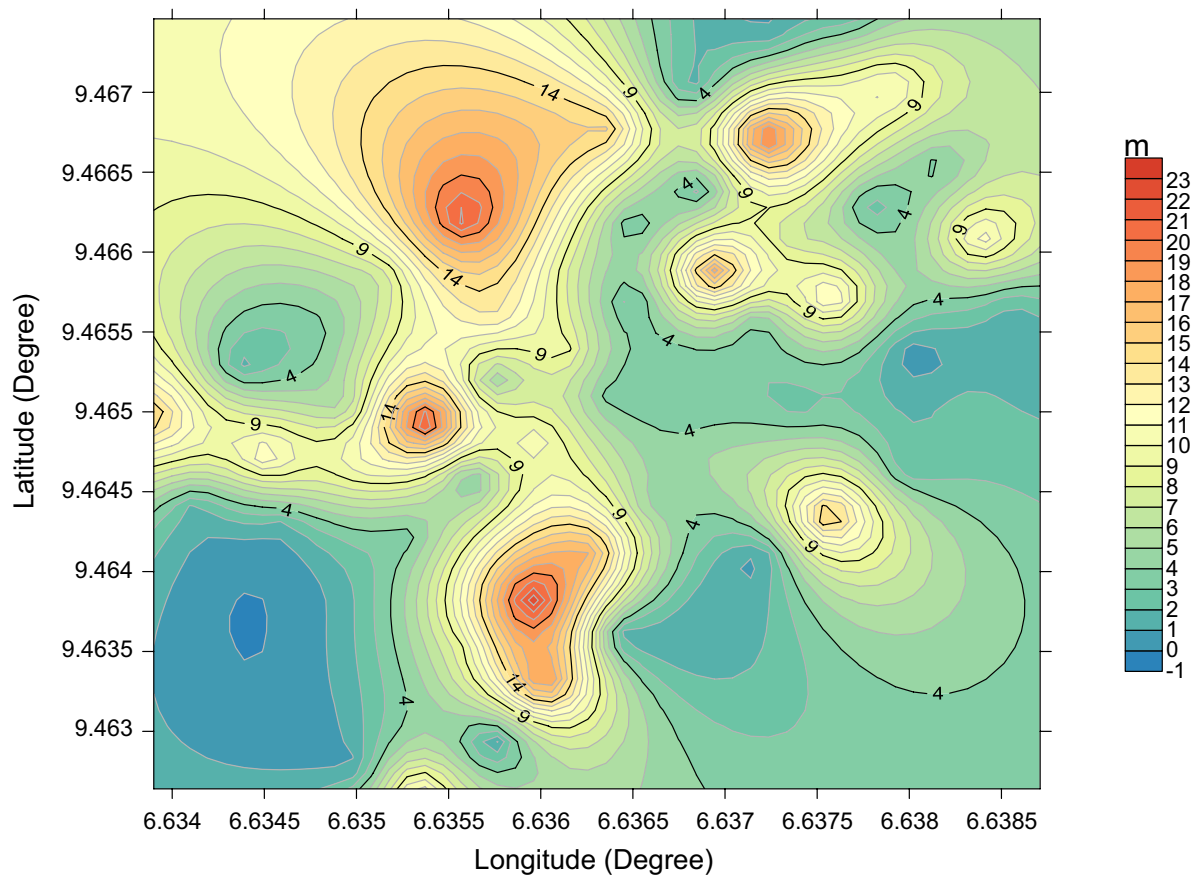

Fig. 9 Isopach map of the overburden

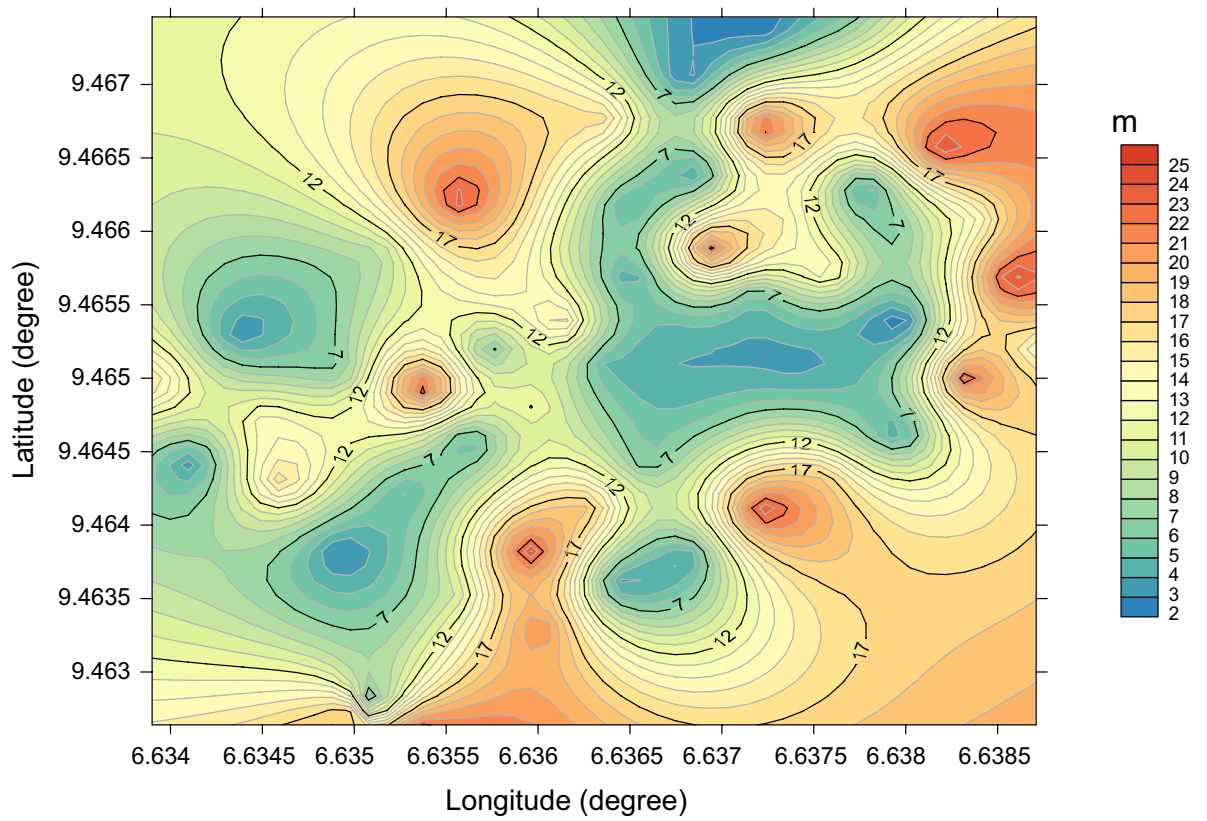

ranging from 12.47 to $22.4 \mathrm{~m}$ and also thickness ranging from 10.68 to $21.2 \mathrm{~m}$.

\section{Recommendations}

- The VES stations delineated for groundwater potentials should be considered for water development
- Areas with poor aquifer protective capacity should be avoided for sinking borehole to reduce leachates infiltration to the ground water 
Fig. 10 Contour map of the longitudinal conductance distribution in the area

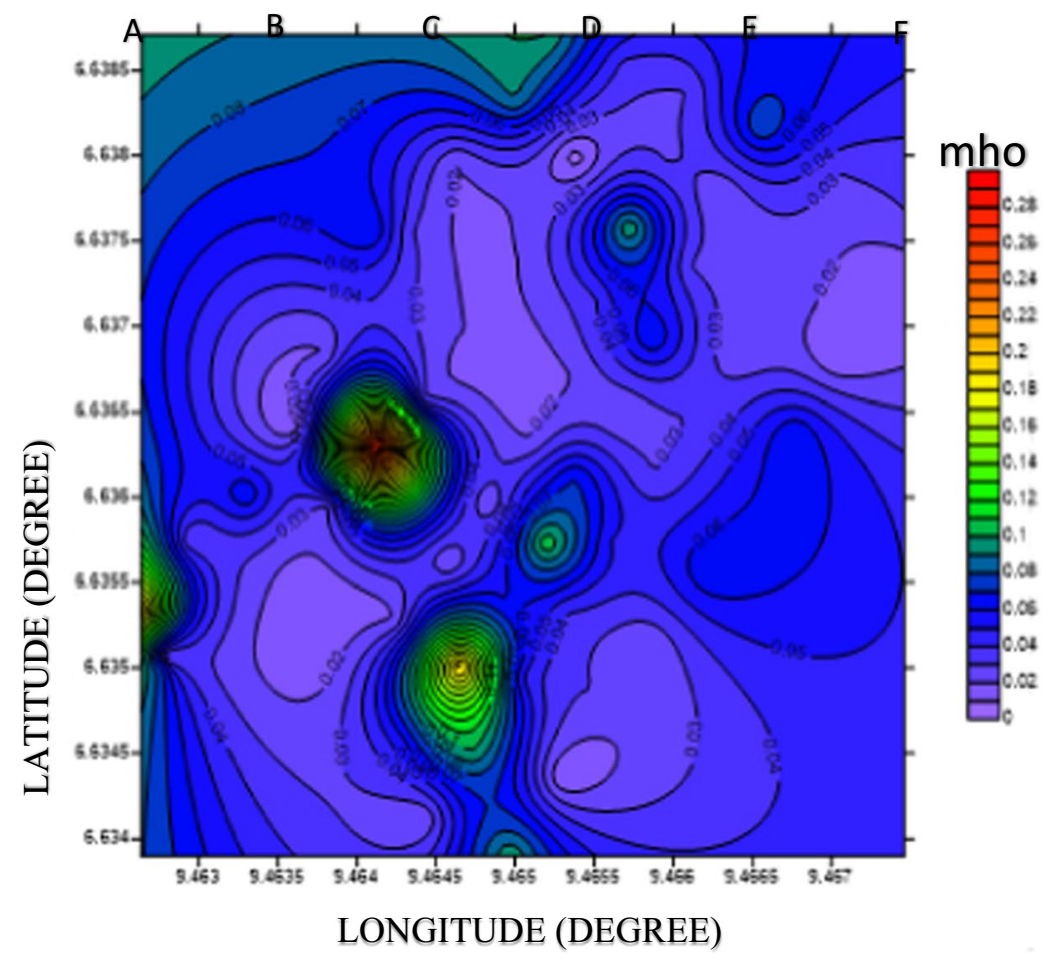

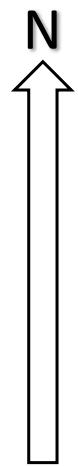

Table 4 Recommended aquifer potentials of the study area

\begin{tabular}{|c|c|c|c|c|c|c|c|}
\hline VES station & Latitude $\left({ }^{\circ}\right)$ & Longitude $\left({ }^{\circ}\right)$ & Layer nos & $\begin{array}{l}\text { Layer resistivity } \\
(\Omega \mathrm{m})\end{array}$ & Layer depth (m) & $\begin{array}{l}\text { Layer thick- } \\
\text { ness }(\mathrm{m})\end{array}$ & Curve type \\
\hline $\mathrm{A}_{1}$ & 09.46521 & 06.63871 & 4 & 118.9 & 13.78 & 11.16 & HA \\
\hline $\mathrm{A}_{5}$ & 09.46410 & 06.63720 & 4 & 367.5 & 26.37 & 24.69 & HA \\
\hline $\mathrm{A}_{8}$ & 09.46330 & 06.63602 & 3 & 293.5 & 21.40 & 19.22 & $\mathrm{H}$ \\
\hline $\mathrm{A}_{10}$ & 09.46264 & 06.63533 & 3 & 108 & 22.40 & 21.20 & $\mathrm{H}$ \\
\hline $\mathrm{B}_{8}$ & 09.46353 & 06.63560 & 3 & 454.9 & 10.61 & 9.255 & $\mathrm{H}$ \\
\hline $\mathrm{B}_{10}$ & 09.46278 & 06.63501 & 4 & 242 & 17.10 & 15.10 & HA \\
\hline $\mathrm{C}_{1}$ & 09.46609 & 06.63838 & 3 & 363.8 & 13.50 & 12.15 & A \\
\hline $\mathrm{C}_{3}$ & 09.46572 & 06.63758 & 3 & 136.6 & 13.37 & 13.04 & $\mathrm{H}$ \\
\hline $\mathrm{D}_{9}$ & 09.46465 & 06.63501 & 3 & 65.84 & 12.47 & 10.68 & $\mathrm{H}$ \\
\hline $\mathrm{E}_{1}$ & 09.46704 & 06.63790 & 3 & 420 & 15.22 & 11.66 & $\mathrm{H}$ \\
\hline $\mathrm{E}_{6}$ & 09.46560 & 06.63574 & 3 & 326.4 & 14.63 & 13.22 & A \\
\hline $\mathrm{E}_{9}$ & 09.46473 & 06.63451 & 3 & 127.2 & 13.68 & 12.41 & $\mathrm{H}$ \\
\hline $\mathrm{F}_{4}$ & 09.46677 & 06.63638 & 3 & 231.9 & 16.50 & 15.29 & $\mathrm{H}$ \\
\hline $\mathrm{F}_{5}$ & 09.46650 & 06.63600 & 3 & 281.7 & 17.17 & 15.61 & $\mathrm{H}$ \\
\hline $\mathrm{F}_{6}$ & 09.46621 & 06.63557 & 3 & 390.9 & 24.08 & 21.88 & A \\
\hline $\mathrm{F}_{10}$ & 09.46497 & 06.63390 & 3 & 180 & 16.64 & 15.51 & $\mathrm{H}$ \\
\hline
\end{tabular}




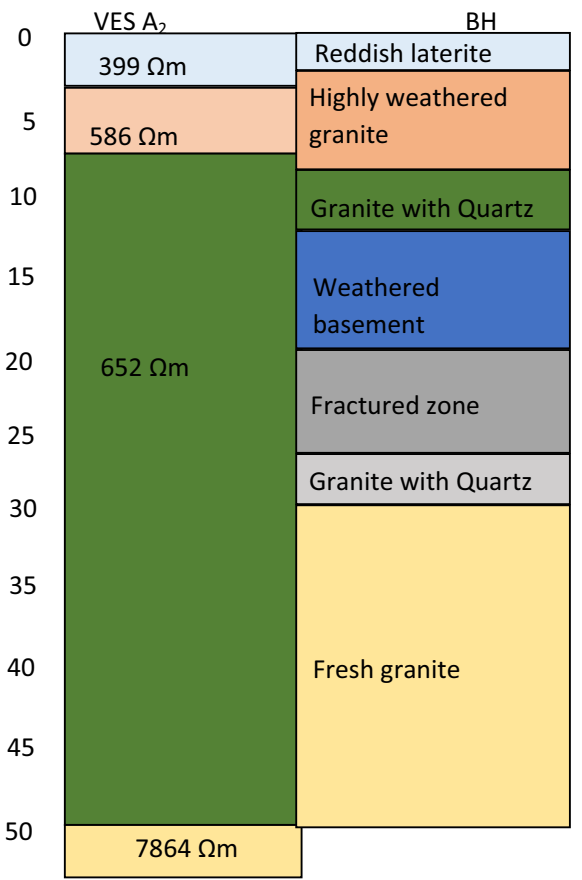

(a) Correlation of VES data with nearby Borehole Log

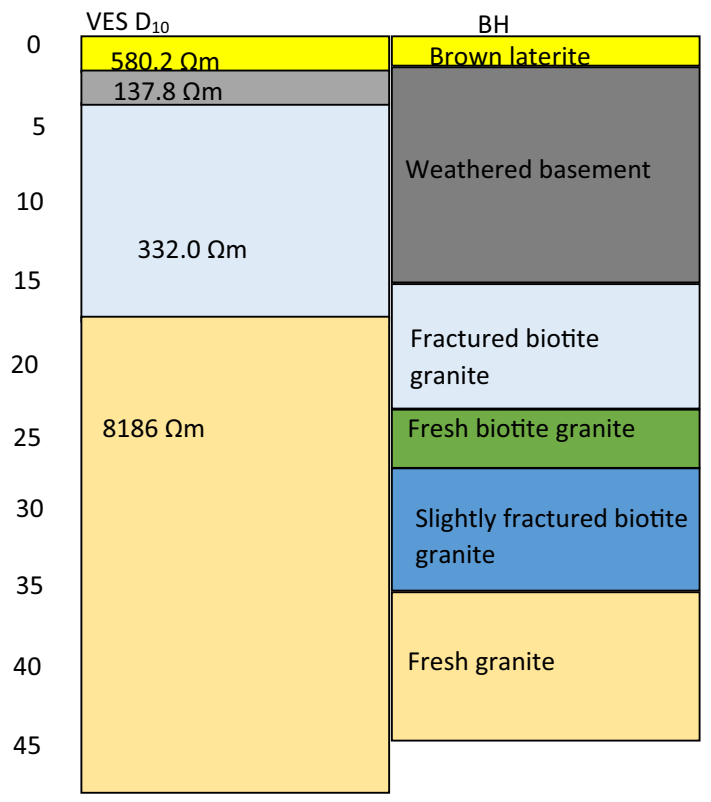

(b) Correlation of VES data with nearby Borehole Log

Fig. 11 a, b Correlation of VES data with nearby borehole log

Open Access This article is distributed under the terms of the Creative Commons Attribution 4.0 International License (http://creativeco mmons.org/licenses/by/4.0/), which permits unrestricted use, distribution, and reproduction in any medium, provided you give appropriate credit to the original author(s) and the source, provide a link to the Creative Commons license, and indicate if changes were made.

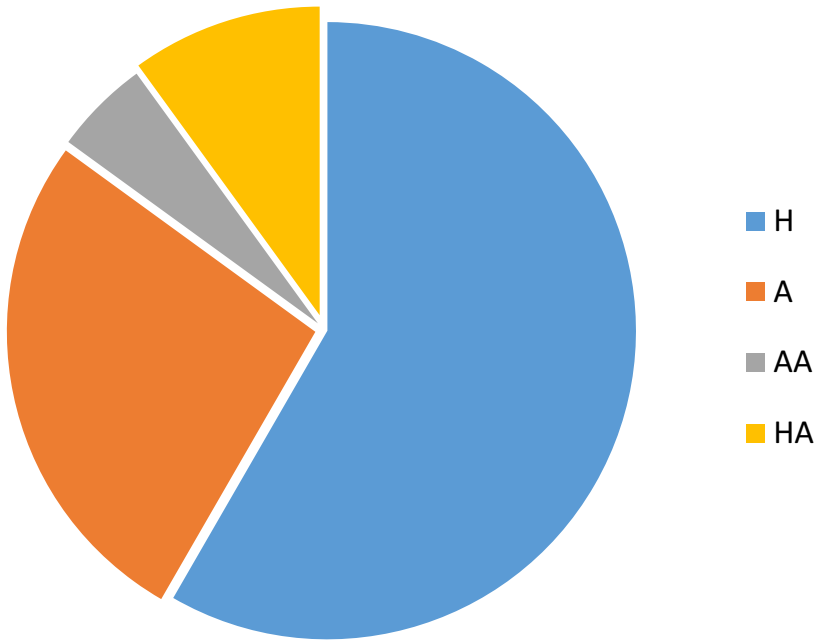

Fig. 12 Chart showing the curve distribution

\section{References}

Ajayi CO, Hassan M (1990). The delineation of the aquifer overlying the basement complex in the western part of the Kubanni basin of Zaria, Nigeria. Unpublished report

Alhassan DU, Obiora DN, Okeke FN (2015) The assessment of aquifer potentials and aquifer vulnerability of southern Paiko, North-central Nigeria using geoelectric method. Global J Pure Appl Sci 21:51-70

Alhassan DU, Obiora DN, Okeke FN (2017) Geoelectrical investigation of groundwater potentials of northern Paiko, Niger state, north central Nigeria. Journal of Earth science 28(1):103-112

Amadi AN, Olasehinde PI, Okoye NO, Momoh OI, Dan-Hassan MA (2012) Hydrogeophysical exploration for groundwater potential in Kataeregi, Northern-Central Nigeria. International journal of Scientific Reseach 2(1):9-17

Baimba AA (1978) Resistivity and refraction methods for groundwater exploration at Zango, Kaduna state. Unpublished M.Sc. thesis $\mathrm{ABU}$, Zaria

George JN, Ibuot JC, Obiora DN (2015a) Geoelectrohydraulic of shallow sandy in Itu, Akwa Ibom State (Nigeria) using geoelectric and hydrogeological measurements. J Afr Earth Sc 110:52-63

George NJ, Emah JB, Ekong UN (2015b) Geohydrodynamic properties of hydrogeological units in parts of Niger Delta, Southern Nigeria. J Afr Earth Sc 105(2015):55-63

Hazell JRT (1992) The location of aquifer in crystalline rocks and alluvium in northern Nigeria using combined electromagnetic and resistivity techniques. Q J Eng GeolHydrogeol 21:159-175

Ogungbemi OS, Badmus GO, Idowu KA (2013) Geoelectric and electromagnetic methods for post foundation studies in a typical basement terrain. Journal of Engineering Trends in Engineering and Applied Science 4(6):863-868

Ojo JS, Olorunfemi MO (1990) Geophysical survey of dam site, a case study. Journal of Mining and Geology 26(2):201-206

Olorunfemi MO, Ojo JS, Akintunde OM (1999) Hydro-geophysical evaluation of the groundwater potential of Akure metropolis, southwestern Nigeria. Journal of Mining and Geology. 35(2):207-228

Omorinbola EO (1984) The water-bearing capacity of regoliths in the Nigerian basement complex. Singap J Trop Geogr 5:165-174 
Salako KA, Adetona AA, Rafiu AA, Ofor NP, Alhassan UD, Udensi EE (2009) Vertical electrical sounding investigation for groundwater at the southwestern part (site A) of Nigeria Mobile Police barracks (MOPOL 12), David Mark road, Maitumbi, Minna. J Sci Educ Technol 2:350-362
Publisher's Note Springer Nature remains neutral with regard to jurisdictional claims in published maps and institutional affiliations. 